\title{
IMFIs Strategy to Survive in the Covid-19 Outbreak and Government Respond Analysis : An Empirical Study from Pekanbaru, Indonesia
}

\author{
Ade Chandra1; Budi Trianto2; Marabona Munthe ${ }^{3}$ \\ Sekolah Tinggi Ekonomi Islam (STEI) Iqra Annisa Pekanbaru123 \\ adec152@gmail.com¹, budi_asamandiri@yahoo.com², \\ munthe_m@gmail.com ${ }^{3}$
}

\begin{abstract}
The Covid-19 outbreak had a broad impact on the economy and also on the business sector. One of the business sectors affected by Covid-19 is Islamic Microfinance Institutions (IMFIs). This study aims to explore the strategies taken by IMFIs during the Covid-19 pandemic and to explore the government's policy response toward the Covid19 disaster. This research was conducted in Pekanbaru using a qualitative approach and using primary data and secondary data in conducting the analysis. Primary data were taken directly from research respondents through in-depth interviews with IMFIs managers. Meanwhile, secondary data were obtained from the government and other sources. The results of this study indicate that the approach strategy taken by IMFIs in responding to the Covid-19 outbreak is a Generic Strategy Approach which consists of cost leadership, focus cost, differentiation and cost differentiation. Meanwhile, the government policy responded taken to save IMFIs from the Covid-19 storm through profit margin subsidies. Unfortunately, the implementation in the field has experienced many obstacles that have greatly disturbed the economic recovery program launched by the government. The results of this study have implications for IMFIs that in order to survive the Covid-19 pandemic, IMFIs must adapt an appropriate strategies. In addition, this study also provides recommendations for the government to simplify the procedure for disbursing profit margin subsidies for IMFIs so that it is hoped that the policy will truly benefit IMFIs and business actors.
\end{abstract}

Keyword: Covid-19, IMFIs, Generic Strategy,Government Policy, Recovery Economy

\begin{abstract}
Abstrak
Wabah Covid-19 berdampak luas pada perekonomian dan juga sektor bisnis. Salah satu bidang usaha yang terkena dampak Covid-19 adalah Lembaga Keuangan Mikro Syariah (LKMS). Studi ini bertujuan untuk mengeksplorasi strategi yang diambil oleh LKMS selama pandemi Covid-19 dan untuk mengeksplorasi respon kebijakan pemerintah terhadap bencana Covid-19. Penelitian ini dilakukan di Pekanbaru dengan menggunakan pendekatan kualitatif dan menggunakan data primer dan data sekunder dalam melakukan analisis. Data primer diambil langsung dari responden penelitian melalui wawancara mendalam dengan pengelola LKMS. Sedangkan data sekunder diperoleh dari pemerintah dan sumber lainnya. Hasil penelitian ini menunjukkan bahwa pendekatan strategi yang diambil oleh LKMS dalam merespon wabah Covid-19 adalah Generic Strategy Approach yang terdiri dari cost leadership, focus cost, diferensiasi dan cost diferensiation. Sementara itu, kebijakan pemerintah direspon untuk menyelamatkan LKMS dari badai Covid-19 melalui subsidi margin keuntungan. Sayangnya pelaksanaan di lapangan mengalami banyak kendala yang sangat mengganggu program pemulihan ekonomi yang dicanangkan pemerintah. Hasil penelitian ini berimplikasi pada LKMS bahwa untuk dapat bertahan dari pandemi Covid-19, LKMS harus segera menyesuaikan strategi
\end{abstract}


yang tepat. Selain itu, studi ini juga memberikan rekomendasi kepada pemerintah untuk menyederhanakan prosedur penyaluran subsidi margin keuntungan bagi LKMS sehingga diharapkan kebijakan tersebut benar-benar menguntungkan LKMS dan pelaku usaha.

Kata kunci: Covid-19, IMFIs, Startegi Generic, Kebijakan Pemerintah, Pemulihan Ekonomi.

\section{INTRODUCTION}

The Corona Virus Disease appeared from Wuhan city as one of province in China at the end of 2019 (COVID-19) and then it has been spreading around the world. In Indonesia COVID-19 detected in March 2, 2020 (Hidayat et. al, 2020). The snow ball multi effects of COVID-19 hit commercial and social life of people the entire world. The impact of the Covid-19 pandemic has almost penetrated all business units in the world, including Indonesia. According to the Indonesian Minister of Finance, there are four most depressed sectors due to the Covid-19 outbreak, namely households, MSMEs, corporations and the financial sector (Mediaindonesia, 2020). Meanwhile, there are six specific sectors affected by the lock down policy implemented by the government, namely the tourism sector, the manufacturing sector, the economy sector, the transportation sector, the social sector and the food sector (Merdeka, 2020).

The aftermath of all that is the reduction of employees as a result of sluggish business and loss of income due to unemployment and business shutdowns. Another more serious impact is the occurrence of an economic recession and this will certainly lead to increased unemployment and poverty. Compared to the baseline projection of 5 percent economic growth in 2020, various studies estimate that COVID-19 would reduce Indonesia's economic growth to between 1 and 4 percent. It finds that under the mildest COVID-19 impact on economic growth, the poverty rate will increase from 9.2 percent in September 2019 to 9.7 percent by the end of 2020. This implies that 1.3 million more people will be pushed into poverty. SMERU Research Institute (2020) estimates the impact of COVID-19 on poverty in Indonesia reach 12,4 percen or 8.5 million new poor people. The latter means that Indonesia's progress in reducing poverty over the last decade would be wiped out. The implication of this is that Indonesia needs to expand its social protection programs to assist the new poor in addition to the existing poor.

One of the sectors that was significantly affected was Islamic microfinance institutions (IMFIs). Based on data from the Ministry of Cooperatives and Small Medium Enterprises of Indonesia, in 2019 have Shariah-Compliant Cooperatives around 4,046 units or $3.29 \%$ of the 123,048 cooperative units. Based on location, the majority of Islamic Cooperatives are located in East Java Province, which around 1,952 units or $48.25 \%$ of all Islamic cooperatives in the country (Hidayat et. all, 2020). Since COVID-19 in Indonesia appeared in the beginning of March 2020, dominantly have effect to all of level of society in the IMFIs. The shock turnover decline for cooperatives member businesses dominated by secondary and tertiary 
IMFIs Strategy to Survive in the Covid-19 Outbreak and Government Respond Analysis : An Empirical Study from Pekanbaru, Indonesia

product trade sector, fisheries sector due to many hotels and restaurants are closed due to the pandemic (Hidayat et. all, 2020). One of the business partners of the IMF is Micro Small and Medium Enterprises (MSMEs). MSMEs are one of the industrial sectors that are affected, either directly or indirectly. Research conducted by Amri (2020) found that the tourism industry is one of the industries affected by the spread of this virus. The sluggish tourism sector has a domino effect on the MSMEs sector.

Based on data processed by P2E LIPI, the impact of tourism decline on MSMEs engaged in micro food and beverage business reached $27 \%$. While the impact on food and beverage small businesses was $1.77 \%$, and medium businesses were $0.07 \%$. The influence of COVID-19 virus on wood and rattan handicraft units, micro businesses will be $17.03 \%$. For small businesses in the wood and rattan handicraft sector $1.77 \%$ and medium businesses $0.01 \%$. Meanwhile, household consumption will also be corrected between $0.5 \%$ and $0.8 \%$. Digital developments in globalization are very influential on the economy, including the retail market. Because of the corona virus, one by one the modern retail market, large scale, micro, to small, began to experience a decline in income. Even with the convenience of shopping, in reality, in the digital age people remain reluctant and prefer to do online shopping or using media applications. Many advantages are offered by online shopping. Some steps to be able to maintain its existence in the market in the digital era such as refocusing the customer and rethinking industry, designing social and digital strategies and developing organizational capabilities.

The decline in the MSMEs business as a result of the Covid-19 pandemic also had a direct impact on IMFIs. MSMEs are one of the main partners of IMFIs, so whatever happens to MSMEs will have an impact on IMFIs. It needs scenarios to bring IMFIs survive and exist during and after Covid-19 outbreak and make appropriate strategies to make sure that IMFIs still sustainable, develop and growth in the short, middle and long-term. Research related to the IMFIs strategy during the Covid-19 pandemic is still very rare. Most researchers are more interested in discussing the impact caused by Covid-19. For example Hidayat (2020) found that Covid -19 had an impact on MSMEs who were in vulnerable groups that occasionally can fall below the poverty line when crisis occurs. Likewise research conducted by Malik et al. (2020) looks more at the MSMEs aspect than the IMFIs strategy in surviving the Covid-19 pandemic. Therefore this research was conducted to fill this gap and this research is important to do in order to get the empirical facts on how the IMFIs strategy in surviving the Covid-19 pandemic. Therefore, In this research, we will explore the choosen strategic by the IMFIs to survive in the Covid-19 pandemic. Therefore, the structure of this research is divided into five stages. Stage 1 introduction which contains the background of the research. Part 2 of the literature review discusses the development of IMFIs in Indonesia, Covid-19 and previous studies. Section 3 research data, empirical framework and analysis approach. Section 4 present empirical findings. Section 5 conclusion and recommendations. The research 
objectives in the research are: 1) To explore an empirical strategy that have been chosen by the IMFIs to survive in the Covid-19 outbreak. 2) To explore the government policy respond

\section{LITERATURE REVIEW}

\section{Islamic Microfinance Institutions}

Islamic Microfinance Institutions (IMFIs) operate on the basis of Islamic principle with several values such as prohibition against usury (riba), excessive uncertainty (gharar), all activities used for permitting purposes (halal) and implement profit and loss sharing (Rahayu, 2020). IMFIs fulfill the needs and demands of the community based on the sharia-compliance instruments. IMFIs is here provide and to help improve the welfare of the Muslim community and highly reduce the poverty (Mawardi et. all., 2020). One of the fast growing IMFIs in Indonesia is Baitul Maal Wat Tamwil (BMT). Based on BMT Association of Indonesia (ABSINDO), Indonesia have 5.806 Islamic Microfinance Institutions in 2019 since the first established in 1990 and more than 98\% operates as Islamic Cooperatives under the law of Minister of Cooperatives and SMEs no.91 in 2004 (Mawardi et. all., 2020). BMT is Islamic Microfinance Institutions (IMFIs) that combine Islamic commercial finance functions as baitul tamwill (treasuries) with social finance functions as baitul maal/house of wealth (Ascarya et al., 2018). In Indonesia, there are two models of Islamic Microfinance, namely BMT and Islamic Rural Bank, both of which can act as social finance and commercial finance (Riwajanti, 2014). The development of Islamic Microfinance has an impact on community development in rural areas, social benefits, religious values and poverty alleviation (Irfan, 2020). Khan (2008) added that Islamic Microfinance is the best theory for addressing the practice of the social development of the nation.

Islamic Microfinance Institutions (IMFIs) in the Pekanbaru city as capital of Province of Riau is categorized into two model such as Islamic cooperative and Islamic Rural Bank (BPRS). During 2019, in the Pekanbaru city there were 469 cooperatives as consist of 441 as Coventional Cooperatives and 28 as Islamic Cooperatives. Furthermore, there are 132 as active cooperatives and 9 as active IsFiC. The 28 Islamic cooperatives in the Pekanbaru city are consisting of 2 as Multi Business Islamic Cooperatives (MBIC) and 26 as Islamic Financing Cooperatives (IsFiC). Then only 2 BPRS has an office in Pekanbaru city such as BPRS Hasanah and BPRS Berkah Dana Fahlillah. IsFiC model in line as 13 Islamic Finance Service Cooperatives (IFSC) and another as 13 BMT (Chandra, 2019).

\section{Covid-19 Outbreak and Government Respond}

Coronavirus disease 2019 (COVID-19) is an infectious disease caused by a newly discovered coronavirus. Most people infected with the COVID-19 virus experience mild to moderate respiratory illness and recover without requiring special treatment. Older people and those with underlying medical 
IMFIs Strategy to Survive in the Covid-19 Outbreak and Government Respond Analysis : An Empirical Study from Pekanbaru, Indonesia

problems like cardiovascular disease, diabetes, chronic respiratory disease, and cancer are more likely to develop serious illness. The best way to prevent and slow down transmission is be well informed about the COVID-19 virus, the disease it causes and how it spreads. Protect ourself and others from infection by washing hands or using an alcohol based rub frequently and not touching your face. The COVID-19 virus spreads primarily through droplets of saliva or discharge from the nose when an infected person coughs or sneezes, so it's important that we also practice respiratory etiquette (for example, by coughing into a flexed elbow). At this time, there are no specific vaccines or treatments for COVID-19. However, there are many ongoing clinical trials evaluating potential treatments (WHO, 2020).

Untill 11 August 2020, 06:58 GMT, in the world there are 20,259,561 coronavirus cases, 739,212 deaths and 13,190,508 recovered (Worldometers, 2020). The Corona Virus Disease (COVID-19) in Indonesia has detected in March 2, 2020 (Hidayat et. all, 2020). Indonesia untill 11 August 2020, 06:58 GMT have 127,083 coronavirus cases, 5,765 deaths and 82,236 recovered (Worldometer, 2020). The linear graph as shown below:

\section{Graph 1. Total Coronavirus Cases in Indonesia}

$15^{\text {th }}$ February - $10^{\text {th }}$ August 2020

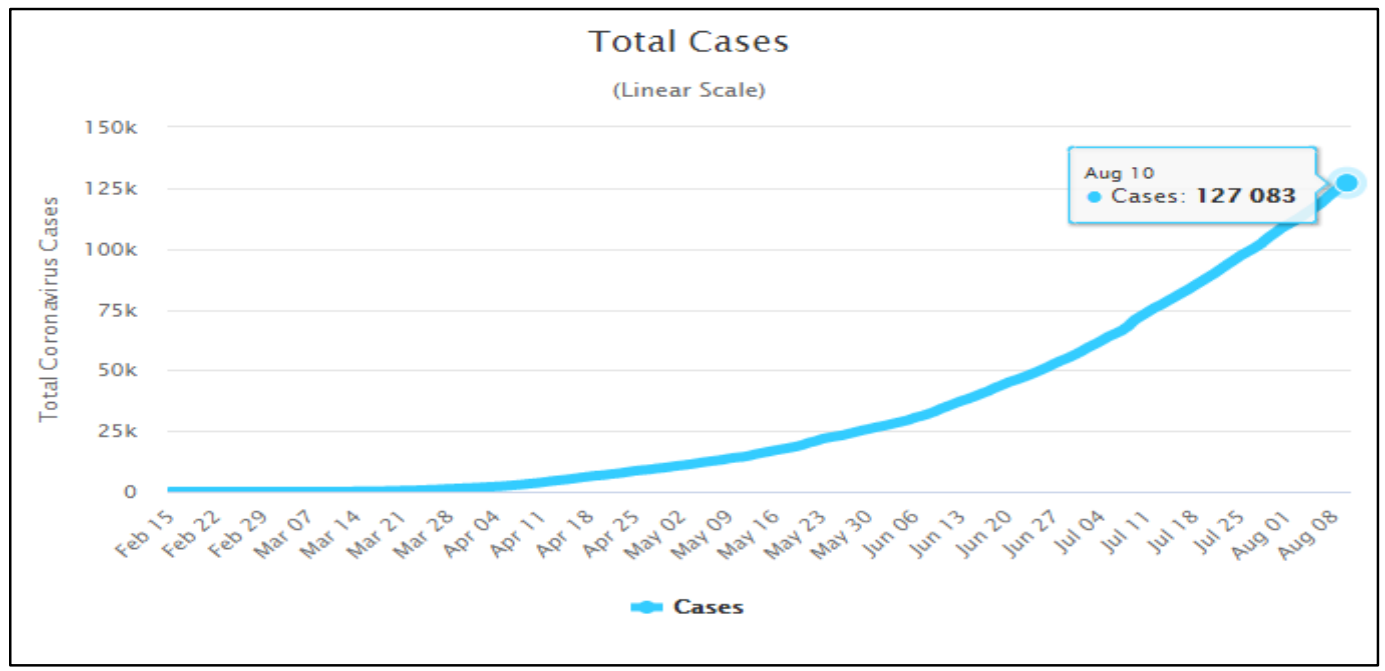

Source: Worldometer, 2020

It needs some scenarios in the respond of COVID-19 outbreak due to the COVID-19 outbreak has global impacts on humanity and the economy. The pandemic effects influence human behaviour; issues of overbuying and non-compliance with government orders and law among individuals. Therefore, the social dilemma theory and microeconomics concepts adopts to analyse and explain the effects of COVID-19 on social behavioural reactions with real scenarios based on media reporting from the sociodemographic in the context of Malaysia, concerning the following issues; (i) competition over 
daily essentials; (ii) self-honesty of individuals; and (iii) adherence to government policies and measures enforcement (Teck \& Christina, 2020). Indonesian government has taken numerous policies to respond the COVID-19 pandemic such as Government Regulation No.43/2020 on the Amendment to Government Regulation No.23/2020 on the Execution of the National Economic Recovery program in the Event of supporting state financial policies in mitigating the COVID-19 pandemic and/or other threats to national economy and/or the stability of financial system as well as in saving the national economy. Minister of Finance Regulation No.98/PMK.08/2020 on the procedures to obtain Government Guarantee for Corporate Business through the appointed Guaranteeing Institutions in carrying out the National Economic Recovery program. The government also has officially launched its Loan Guarantee for Small-and-medium-sizedenterprise Program as regulated under the Indonesian National Economic Recovery effort in mitigating the economic impact of COVID-19. As much as Rp 123.46 trillion (over US $\$ 8.5$ million) have been set aside to fund this program (EKONID, 2020).

\section{Strategic Management for a Business}

A strategy is defined as a comprehensive approach that states how business will achieve its mission and objectives. Strategic management is a set of managerial decisions and actions that help determine the long-term performance of an organization (Wheelen et al., 2018). Three most highly benefits of strategic management are: (1) a clearer sense of strategic visions for the firm, (2) a sharper focus on what is strategically important, (3) an improved understanding of rapidly changing environment (Wheelen et al., 2018). Michael Porter proposed three "generic" competitive strategies for outperforming other organizations in a particular industry: overall cost leadership, differentiation and focus. These strategies are called generic due to it can be pursued by any type or size of business firm, even by non-profit organzations. Cost leadership is the ability of a company or a business unit to design produce and market a comparable product or service more efficiently than its competitors. Differentiation is the ability of a company to provide unique and superior value to buyer. This may include areas such as product quality, special features of after-sale service. Focus is the ability of a company to provide unique and superior value to a particular buyer group, segment of the market line or geographic market.

Porter proposed that a firm's competitive advantage in an industry is determined by its competitive scope as the breadth of the company's or business unit's target market (broad target such as middle or the mass market, or a narrow market). When the competitive scope to combine with these two target markets with three generic strategies results in four variations of generic strategies such as cost leadership, differentiation, cost focus and differentiation focus, as graph below: 
IMFIs Strategy to Survive in the Covid-19 Outbreak and Government Respond Analysis : An Empirical Study from Pekanbaru, Indonesia

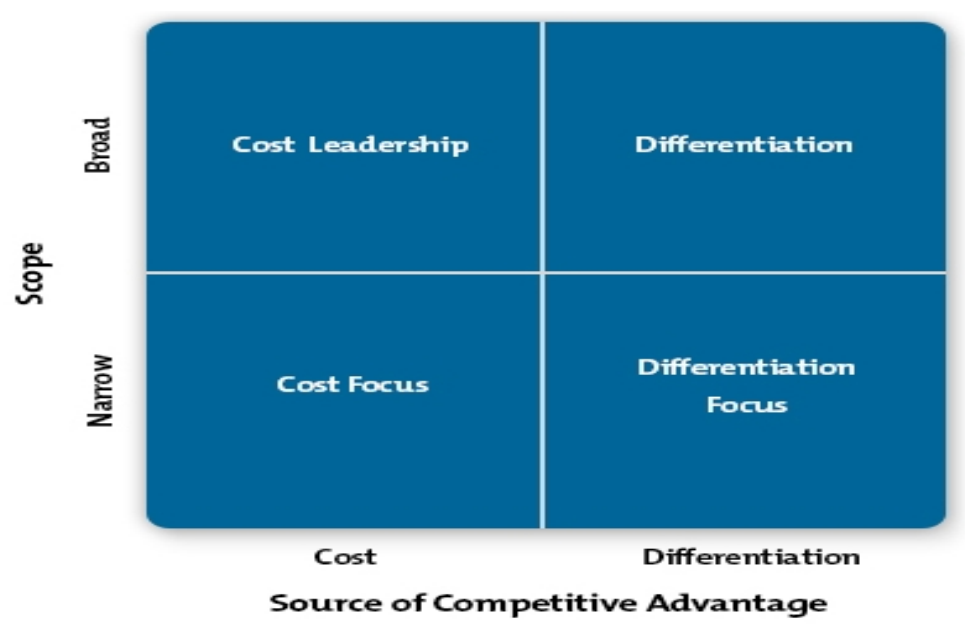

Figure 1 : Combination of Porter's Generic Strategies

Source: Mindtools, 2007

Huy (2020) explained that COVID-19 has brought on a business crisis. The pandemic represents VUCA (Volatility, Uncertainty, Complexity, Ambiquity) world. Then fundamentally reshape how business run from now on. Some of key strategic priorities will be modified in a radical way. To start, the basic purpose of business strategy is to steer companies towards sustainable sources of growth and profit. The new priorities strategy needs to put on the radar for the years to come are:

1. Aim for survivability and resilience before economic efficiency. In the post-COVID-19 world, contingency planning should be build into every link of the value chain to ensure survival.

2. Quantify and plan for ecological and environmental threats rather than just describe them. It needs in depth forethought about how to deal with it should arise.

3. Build a strong organisational immune system rather than maximize short-term profits. The companies need long, sensitive feelers and hyperresponsive capability at all levels of the organization to stay in the pink of the health. Build an organizational culture based on the following motto: "No news is bad news; bad news is good news; good news is no news."

4. Integrate government politics rather than focusing only on business economics. Create big opportunity for some firms that integrate government politics into business strategies. Homegrown innovation capability will be valued by national governments and benefit from higher economic and regulatory support. Additionally, rising patriotismcreating "good" jobs for our own people-could benefits these firms in our countries.

Strategy after COVID-19 will be less about beating our economic competitors and more about how business can contribute to combating a larger, shared enemy. The COVID-19 "new-normal" may actually be a return 
to an older equilibrium between business and society and wide stakeholder collaboration.

\section{Previous Studies}

The Covid-19 outbreak is a world disaster at the end of 2019 and must be handled seriously and must be carried out with proper disaster management. Al-Eid and Arnout (2020), conducted an investigation related to the disaster management of the Covid-19 outbreak with an Islamic approach. The grounded theory approach was applied, which is one of the qualitative designs. The results of the qualitative analysis of the verses of the Qur'an and the hadiths of the Prophet's noble Sunnah have resulted in four concepts that constitute a broad conceptual theory of crisis management according to the Islamic approach. These concepts are crisis management strategies in Islam, the stages of crisis management, the characteristics of a leader who manages crises, and the roles of a leader during the crisis management process. A number of assumptions have been made of this generated theory about Islamic crisis management model. In light of the results of this study, recommendations were formulated that indicate the necessity of training leaders in the Islamic approach to crisis management, its strategies and its scientific steps in crisis management.

Teck and Ho (2020), examines the impact of Covid-19 on social dilemmas by adopting social dilemma theory. This paper demonstrates the relevancy of the social dilemmas theory in better understanding fundamental human behavioural reactions amid the health crisis and the importance of incorporating the findings into government policymaking. These sociopsychological considerations help the government formulate holistic measures, namely stringent sanctions and monitoring enforcement, as well as incentivising cooperative and compliant behaviours of the public, which then contribute to curbing COVID-19 pandemic more effectively.

Meanwhile, Malik et al (2020) examined the impact of Covid-19 on microfinance institutions in Pakistan. The research focus on a mature microfinance sector, serving a large number of households. The institutions serve populations poorly-served by traditional commercial banks, helping customers invest in microenterprises, save, and maintain liquidity. The report results from 'rapid response' phone surveys of about 1,000 microenterprise owners, a survey of about 200 microfinance loan officers, and interviews with regulators and senior representatives of microfinance institutions. The research ran these surveys starting about a week after the country went into lockdown to prevent the spread of the novel coronavirus. The research find that, on average, week-on-week sales and household income both fell by about $90 \%$. Households' primary immediate concern in early April became how to secure food. As a result, $70 \%$ of the sample of current microfinance borrowers reported that they could not repay their loans; loan officers anticipated a repayment rate of just 34\% in April 2020. 
IMFIs Strategy to Survive in the Covid-19 Outbreak and Government Respond Analysis : An Empirical Study from Pekanbaru, Indonesia

The results to argue that COVID-19 represents a crisis for microfinance in low-income communities.

One of the main partners of IMFIs are MSMEs which are also affected by Covid-19. Hardilawati (2020) conducted a study on how MSME strategies can survive in a situation full of uncertainty. This study used qualitative analysis with exploratory participatory observation techniques. The result of this study recommend 4 ways a survival strategy for SMEs. There is using ecommerce for business, using digital marketing, improving product and service quality and optimizing customer relationship marketing. The results are important to be understood and adopted by SMEs and hopefully they always responsive and adjusting to business environment to survive. Sultan and Sultan (2020) investigate the women MSMEs in the Palestinian that to survive in the crisis of Covid-19, they should make an innovation strategies so they will survive during the economic crisis. Fitriani (2020) also conducted an evaluation of the Cash For Work (CFW) program to help MSMEs survive the Covid-19 pandemic conducted by BAZNAS, showing that the program is quite effective in helping business actors. This program can be combined with Qardhul Hasan funds as a result of research conducted by Syed et al (2020) to help business actors survive a crisis.

\section{METHODOLOGY}

\section{Data}

This study uses primary data taken directly from respondents. As for the respondents of this study were the managers of IMFIs in Pekanbaru. Respondents were selected based on the characteristics of IMFIs, where the characteristics we define are IMFIs that have received recognition from the government because of their performance. Based on the criteria we have determined, we have obtained 3 IMFIs that we deem appropriate for us to become respondents. The three IMFIs are BMT Islam Abdurrab, BMT AlIttihad and BMT Mitra Artha. Therefore, the respondents in this study were three BMT managers. The data were obtained by conducting in-depth interviews with the three BMT managers as respondents.

\section{Method}

In this study, the researchers used qualitative descriptive approach to describe, explain, and interpret the collected data (Williams, 2007). Qualitative research means the research which explores and comprehends individual meaning, social group or human problems (Creswell, 2014). The research characteristic of qualitative method is adherence to understanding social life aspects generally by words or sentence (Bricki \& Green, 2017). Data were collected through in-depth interviews with respondents. Following is research framework : 


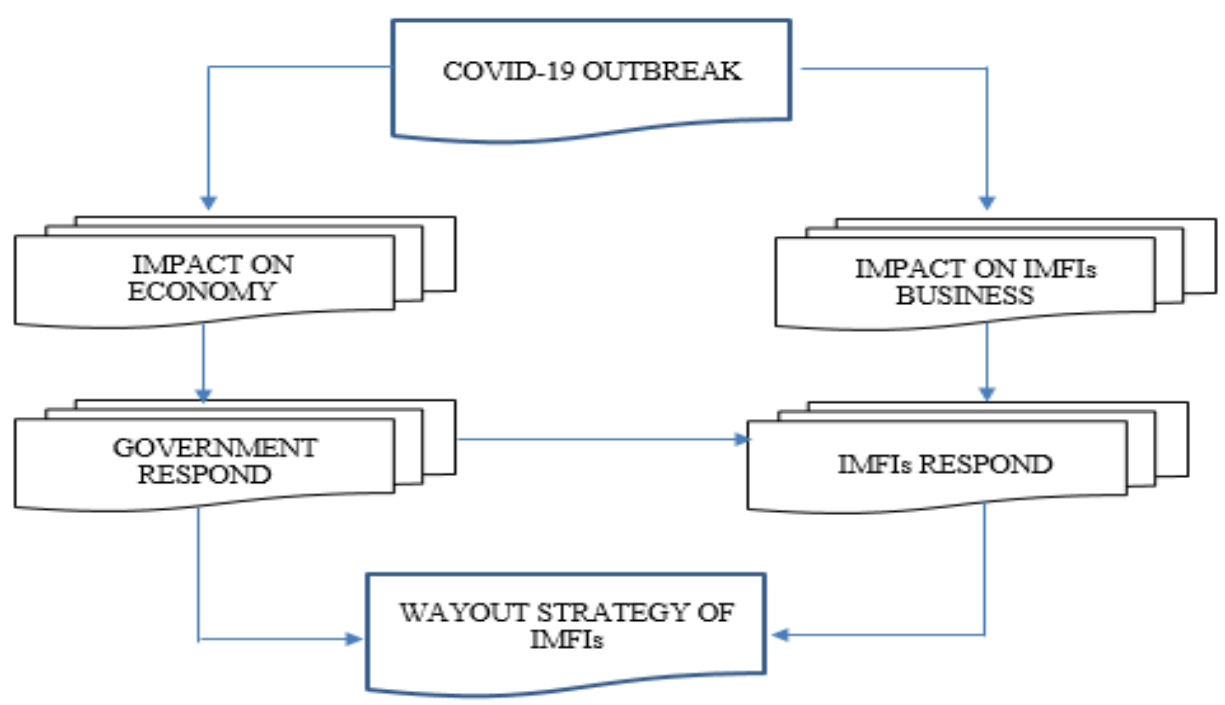

Figure 1: Research Framework

\section{RESULT AND DISCUSSION \\ Government Policy Respond Review}

One of those affected by Covid-19 is the economic sector. The sectors of the economy that are directly affected are MSMEs. To overcome the impact on this economic sector, the Indonesian government made several policies. The government issued a government regulation in lieu of law (PERPU) No.1 of 2020. PERPU No.2 of 2020 contains state financial policies and financial system stability to handle the Covid-19 pandemic and / or in the context of facing threats that endanger the national economy and / or financial system stability. Furthermore, the PERPU was changed to Law No.2 of 2020. To follow up on Law no. 2 of 2020, several ministries issued operational policies.

The Ministry of Finance has issued Minister of Finance Regulation (PMK) No. 85 / PMK.05 / 2020, this regulation revokes PMK No. 65 / PMK.05 / 2020. Then PMK No. 85 / PMK.05 / 2020 was revoked and replaced by PMK No. 138 / PMK.05 / 2020 concerning procedures for providing interest subsidies or margin subsidies in order to support the implementation of the national economic recovery program. This policy certainly gives encouragement to business actors and also to Islamic financial institutions such as the Islamic Cooperative. For business actors, bill burdens as a result of the financing they make will be helped by this policy. For Islamic cooperatives, the margin subsidy that the government provides to them will be used as a margin reduction for Islamic cooperative members who carry out financing so that the burden on members becomes lighter during the Covid-19 pandemic. 
IMFIs Strategy to Survive in the Covid-19 Outbreak and Government Respond Analysis : An Empirical Study from Pekanbaru, Indonesia

Table 1 : Government Policy Respond During Covid-19 for IMFIs and MSMEs

\begin{tabular}{|c|c|c|}
\hline No & Policy & Remarks \\
\hline 1 & $\begin{array}{l}\text { PERPU No.1/2020 and } \\
\text { UU No. } 2 / 2020\end{array}$ & $\begin{array}{l}\text { State financial policies and financial } \\
\text { system stability to handle the Covid-19 } \\
\text { pandemic. }\end{array}$ \\
\hline 2 & $\begin{array}{l}\text { PMK } \\
\text { No.65/PMK.05/2020 }\end{array}$ & $\begin{array}{l}\text { Procedures for the provision of interest } \\
\text { subsidies/margin subsidies for credit or } \\
\text { financing micro, small and medium } \\
\text { enterprises in supporting the } \\
\text { implementation of the national economic } \\
\text { recovery program. }\end{array}$ \\
\hline 3 & $\begin{array}{l}\text { PMK } \\
\text { No.85/PMK/05/2020 }\end{array}$ & $\begin{array}{l}\text { - } \\
\text { - } \\
\text { Proplaced of PMK No.65/PMK.05 for the provision of interest } \\
\text { subsidies/margin subsidies for credit or } \\
\text { financing micro, small and medium } \\
\text { enterprises in supporting the } \\
\text { implementation of the national economic } \\
\text { recovery program. }\end{array}$ \\
\hline 4 & $\begin{array}{l}\text { PMK } \\
\text { No.138/PMK/05/2020 }\end{array}$ & $\begin{array}{ll}\text { - } & \text { Replaced of PMK No.85/PMK.05/2020 } \\
\text { Procedures for the provision of interest } \\
\text { subsidies/margin subsidies for credit or } \\
\text { financing micro, small and medium } \\
\text { enterprises in supporting the } \\
\text { implementation of the national economic } \\
\text { recovery program. }\end{array}$ \\
\hline 5 & $\begin{array}{l}\text { Permenkop No. } 22 \\
\text { Tahun } 2020\end{array}$ & $\begin{array}{l}\text { Procedures for submitting data on } \\
\text { cooperative debitors in the context of } \\
\text { providing interest subsidies / margin } \\
\text { subsidies for credit or financing for the } \\
\text { MSMEs sector }\end{array}$ \\
\hline 6 & $\begin{array}{l}\text { Permenkop No.4 Tahun } \\
2020\end{array}$ & $\begin{array}{ll}\text { - } & \text { Loan/financing } \\
\text { - } & \text { Revolving Fund Management Institute } \\
\text { (LPDB) as a responsible as a channel for } \\
\text { loan funds }\end{array}$ \\
\hline
\end{tabular}

A part from regulations from the Ministry of Finance, the Government also makes policies through the Ministry of Cooperatives and Small and Medium Enterprises (KUKM Ministry). The Ministry of KUKM issued Regulation of the Minister of Cooperatives (Permenkop) No. 22 of 2020 concerning procedures for submitting data on cooperative debitors in the context of providing interest subsidies / margin subsidies for credit or financing for the MSMEs sector. The Permenkop is a response to a policy issued by the Ministry of Finance of the Republic of Indonesia. Permenkop No. 22 of 2020 is a technical guide for financial assistance for MSMEs affected 
by Covid-19 which is channeled through cooperatives including the Islamic Cooperative. In addition to this policy, the Ministry of KUKM also issued Permenkop No.4 of 2020 concerning Loans / Financing which is managed by the Revolving Fund Management Institute (LPDB). This policy is to respond to the national economic recovery as a result of Covid-19, so that LPDB is given 100 percent rights to distribute directly to cooperatives and MSMEs (Tribunnews, 2020).

\section{IMFIs Strategy Respond Review}

Islamic Micro Finance Institutions (IMFIs) are one of the institutions directly affected by Covid-19. The direct impact felt by IMFIs is failure to pay members who carry out financing, loss of business partners / members, difficulties in developing a business, and difficulty finding new members. Although the government has made policies to deal with the impact of Covid19 through the Ministry of Finance and the Ministry of Cooperatives, implementation in the field has encountered various obstacles. The obstacles ranged from the invalid IMFIs and MSMEs data to the unsynchronized data obtained from state banks. As a result, until this paper was written, the funds provided by the central government could not be obtained. Of course this is a heavy blow for Islamic Cooperative and MSMEs in Pekanbaru City and even for Riau Province.

However, they must still survive even in difficult circumstances. Therefore IMFIs must make a strategy to survive in conditions full of uncertainty. The results of this study indicate that there are at least three strategies used by IMFIs in Pekanbaru City to survive, namely the competitive strategy. In terms of competitive strategy, IMFIs carries out several activities, namely finding and retaining business partners. In this case, IMFIs made several strategies, including providing qardhul hasan for financing members who have the opportunity to maintain and develop their business. Meanwhile, IMFIs also focuses on prospective members who have fixed income who are not affected by Covid-19. In the economic seminar activities conducted by Bank Indonesia representatives of Medan, there were several groups of people who were not affected by Covid-19, namely people with fixed income such as civil servants or company employees. In addition, there are also groups of people who have experienced an increase in income during the Covid-19 pandemic (Bank Indonesia, 2020). This community group is currently the focus of IMFIs to develop their business.

Table 2 : IMFIs Respond Strategies

\begin{tabular}{|c|c|c|}
\hline No & Strategy & Remarks \\
\hline 1 & Competitive Strategy & $\begin{array}{ll}\text { - } & \text { Providing qardhul hasan } \\
\text { - } & \text { IMFIs focuses on prospective members } \\
\text { who have fixed income who are not } \\
\text { affected by Covid-19 }\end{array}$ \\
\hline 2 & Strategy to overcome & - $\quad$ IMFIs rescheduled installments and \\
\hline
\end{tabular}


IMFIs Strategy to Survive in the Covid-19 Outbreak and Government Respond Analysis : An Empirical Study from Pekanbaru, Indonesia

\begin{tabular}{lll}
\hline & & \\
\hline $\begin{array}{l}\text { defaults of cooperative } \\
\text { members who provide } \\
\text { financing }\end{array}$ & - delayed payments \\
\hline $3 \quad$ Internal Management & - Laying off non-permanent employee \\
& - Postponed employee salary increases \\
& - Postponed new recruitment \\
& - Postponed of the use of fund are not \\
& important \\
\hline
\end{tabular}

Source : Authors Findings, 2020

The second strategy adopted by IMFIs is a strategy to overcome defaults of cooperative members who provide financing. In this case, IMFIs rescheduled installments and delayed payments. Financing installment rescheduling is carried out within a certain period of time and returns to the original installment if conditions are back to normal. Financing installment rescheduling is made according to the member's ability with the minimum nominal value. In addition to rescheduling of financing installments, several IMFIs provide food aid directly to financing members who are directly affected, such as their businesses being closed due to lockdowns in the form of rice, sugar and cooking oil.

The third strategy adopted by IMFIs is a strategy to maintain internal stability of IMFIs. The strategy adopted by IMFIs is to rationalize the company by laying off honorary employees whose positions are not strategic for IMFIs. This is done as an effort to balance IMFIs finances so that they can continue to operate optimally and effectively. Besides rationalizing employees, IMFIs also postponed employee salary increases but did not reduce their salaries. This is done so that existing employees remain motivated to do work. Some IMFIs also postpone new recruitment until conditions become normal, so that they optimize existing employees. IMFIs also postponed the use of funds and budgets that did not provide added value and income for IMFIs.

\section{Analysis of IMFIs Strategy and Government Policy}

IMFIs are one of the most important components in developing an Islamic economy, so that their existence must be maintained and strived to continue to develop properly. The Covid-19 outbreak is a big challenge for IMFIs, whether it can survive or not. There are several things that we can analyze related to the strategies taken by IMFIs in defending their existence from this Covid-19 storm. The strategy taken by IMFIs Pekanbaru is included in the Generic Strategies developed by Porter's. Generic Strategies initiated by Porter's includes cost leadership, differentiation, focus cost and differentiation focus.

The cost leadership concept implemented by IMFIs as an effort to remain competitive is that they make cost reductions to enter the market, tight cost and overhead control. They also carry out cost minimization in services, sales 
force, promotion and so on. The differentiation strategy taken by IMFIs is to create services and product value differentiation from competitors for earning above average returns. Cost focus strategies is low-cost competitive strategy focus on particular market or geographic market to serve only the niche. The IMFIs using cost focus to seek a cost advantage in its target segment. Meanwhile, differentiation focus strategy of IMFIs is concentrate on particular market. The IMFIs seeks differentiate in a targeted market segment.

Table 3 : Generic Strategy by IMFIs

\begin{tabular}{llll}
\hline No & \multicolumn{1}{c}{ Strategy } & \multicolumn{1}{c}{ Remarks } \\
\hline 1 & Cost Leadership & - & Cost reduction \\
& & - & Thight Cost \\
& & - & Overhead control \\
\hline 2 & Differetiation & - & Product value differentiation \\
& & - & Service value differentiation \\
\hline 3 & Focus Cost & - & Geographic market \\
& & - & Target Segment \\
& & - & Concentrate on particular market \\
\hline 4 & Differentiation Focus &
\end{tabular}

The government's role is also important to support the existence of IMFIs following the Covid-19 outbreak. At least the government has made various efforts to support national economic recovery, although in implementation there are many obstacles. The government's support for the existence of IMFIs is by implementing several policies and regulations. The government has made regulations to include IMFIs able to run their activities. The government has also made procedures to give IMFIs time and optimism breadth. To support the operations of IMFIs, the government disburses loan funds that can be used by IMFIs to develop their businesses. The two factors mentioned above, namely IMFIs strategies and Government Policy are a form of scenario for IMFIs to continue to exist, grow, develop and sustainably. The above factors involve one another and inherent in short and long time. Each of them related and giving effects and impacts for IMFIs survival.

Table 4 : Government Respond Analysis

\begin{tabular}{|c|c|c|}
\hline No & Respond & Remarks \\
\hline 1 & Policies & 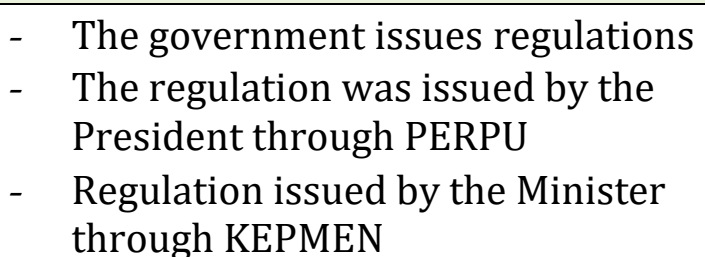 \\
\hline 2 & Regulations & - $\quad$ PERPU No.1/2020 \\
\hline
\end{tabular}


IMFIs Strategy to Survive in the Covid-19 Outbreak and Government Respond Analysis : An Empirical Study from Pekanbaru, Indonesia

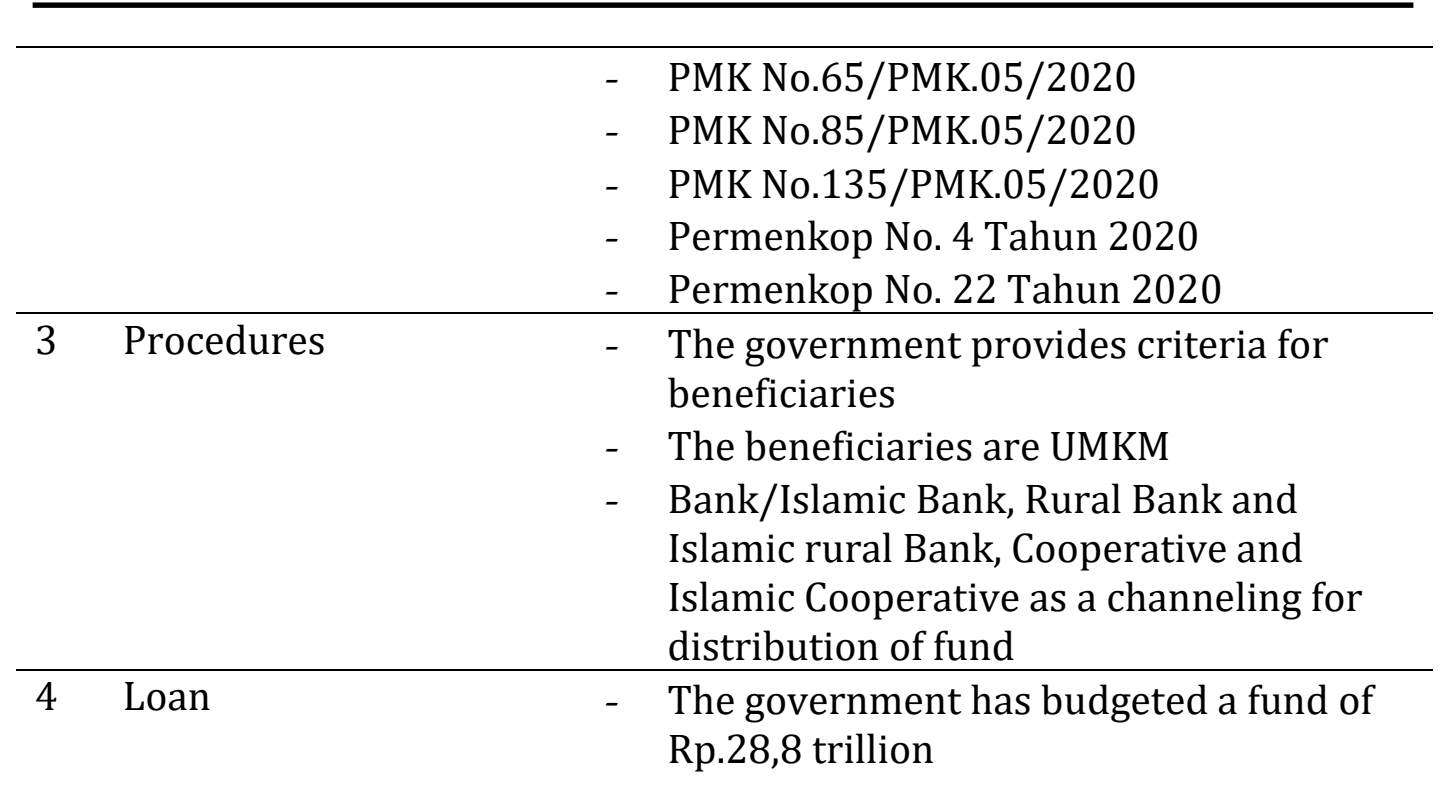

Source : Authors Findings, 2020

The policy taken by the government regarding margin subsidies assistance for IMFIs has a many problems, including a lot of data that is not synchronized between the central government data and the data provided by the cooperative office, as a result, many of these data are invalid so that the promised assistance cannot be disbursed. This of course will hamper the process of economic recovery proclaimed by the government. Even so the government's response to the impact of Covid-19 for business players and the response of IMFIs in maintaining their existence from the impact of Covid-19 is a good effort so that IMFIs can survive, grow and develop so that the sustainability of Islamic Cooperative can be maintained. The following is a framework scenario for IMFIs relief from the Covid-19 storm. 


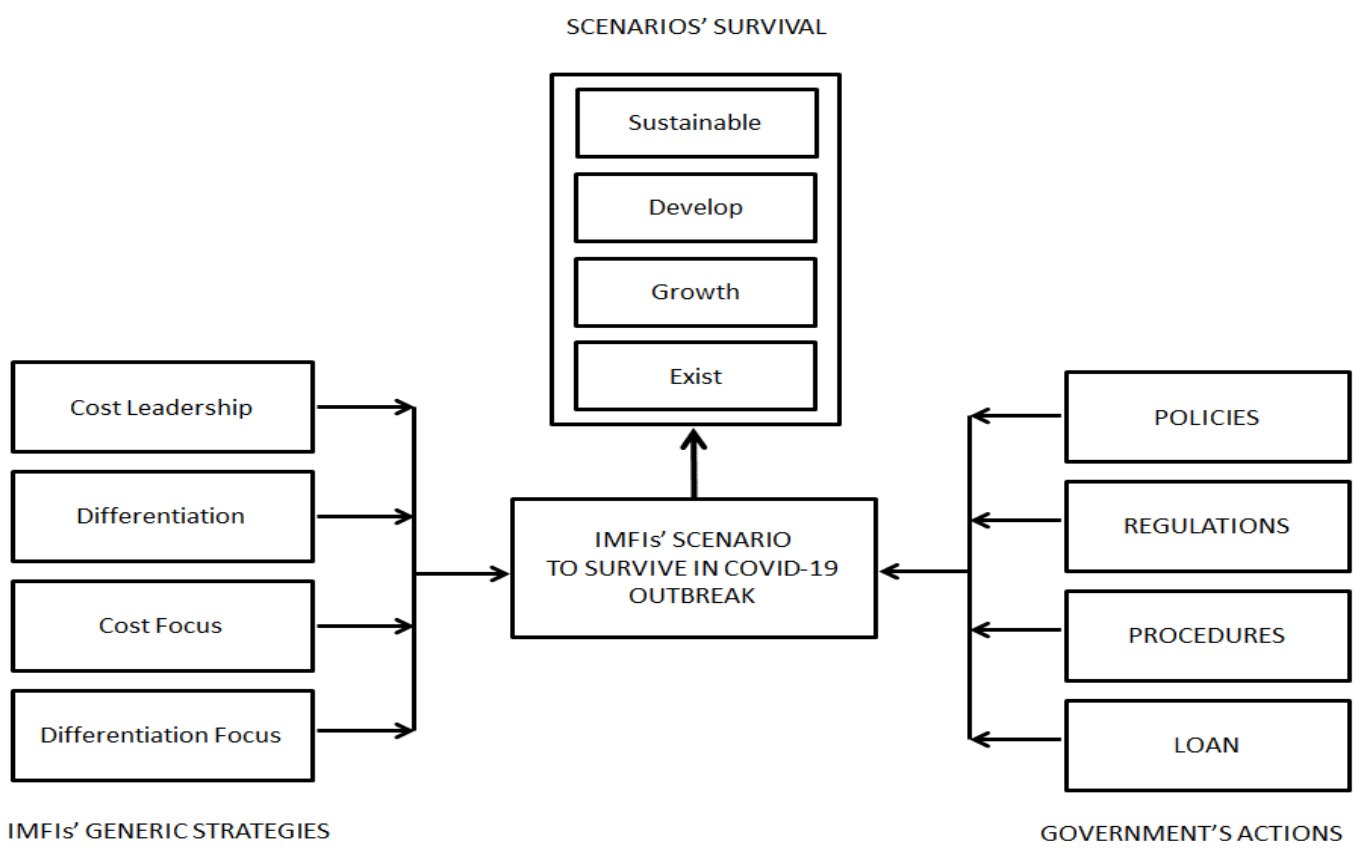

Graph 3. IMFIs' Scenario to Survive in COVID-19 Outbreak

The results of this study indicate that in order to survive the Covid-19 pandemic, IMFIs in Pekanbaru adopted a competitive strategy by providing assistance with a qardhul hasan scheme for business partners who have the potential to enter poverty. The purpose of providing this assistance is so that business partners can rise again. The results of this study are in line with the recommendations given by Malik et al (2020), Hidayat (2020) and Fitriyani (2020) that for MSMEs who are vulnerable to crises, they must be saved with a donation assistance scheme. The results of this study are also in line with Maikabara (2020), that the charity based model of the Islamic Microfinance can absolutely contribute to minimize the impact of Covid-19 and can even be combined with other social funding schemes such as zakat (Syed et al., 2020). Thus, the business continuity of IMFIs can run well during the Covid19 pandemic and that of the post-Covid-19. With the success of IMFIs' business partners, it will provide greater opportunities for IMFIs to survive because they can be again supported by business partners in the form of financing installment payments or implementing new financing. For this reason, it is important for IMFIs to maximize their social function in countering of crisis.

\section{CONCLUSION AND RECOMMENDATIONS \\ Conclusion}

In order to survive the uncertain conditions as a result of the impact of Covid19, IMFIs has implemented several strategies to survive, grow, develop and sustain. IMFIs uses Porters Generic Strategy approach which consists of cost leadership, differentiation, focus cost and differentiation focus. The strategy 
IMFIs Strategy to Survive in the Covid-19 Outbreak and Government Respond Analysis : An Empirical Study from Pekanbaru, Indonesia

adopted by IMFIs is supported by government policies that support the existence of IMFIs in order to continue to grow, develop and sustainably through several policies followed by regulations and procedures. Fundamentally, COVID-19 pandemic gives positive action and solution when IMFIs able to adapt the condition and doing innovation combining with creativity and strategies. However, this study has limitations in terms of the sample. Therefore, for further research, the number of samples can be increased. With a larger research sample, it is hoped that it will provide more insight about the right strategy to survive IMFIs in Covid-19 outbreaks.

\section{Recommendations}

IMFIs are one of the main drivers of Islamic economy, therefore their existence must be continuously pursued and developed in order to be able to make a real contribution to the ummah. Researchers recommend that IMFIs adapt strategies and carry out various innovations so that they can survive and develop during and after Covid-19. Furthermore, the researcher recommends the government to make simpler procedures related to policy implementation, so that the policy will actually provide benefits to IMFIs at the right time and time.

\section{REFERENCES}

Amri, A. (2020). The Impact COVID-19 to SMEs in Indonesia (Dampak COVID19 Terhadap UMKM di Indonesia). Jurnal Brand, Vol. 2 No. 1, 123-130.

Ascarya., Rahmawati, S. and Tanjung, H. (2018). Designing Holistic Financial Inclusion Based on Maqasid al-shari'ah. Islamic Finance, 248: 1004-7.

Bricki, N and Green, J. (2007). A Guide to Using Qualitative Research Methodology. UK: Medecins Sans Frontieres.

Cambridge

Dictionary. https://dictionary.cambridge.org/dictionary/english, accessed on 11 August 2020.

Chandra, A. (2019). Dimension of Good Cooperative Governance Conventional Cooperative and Islamic Cooperative in Pekanbaru (Dimensi Good Cooperative Governance Koperasi Konvensional dan Koperasi Syariah di Pekanbaru), Jurnal Al-Amwal, 8 (2), p.165-179.

Creswell, J.W.(2014). Research Design, Qualitative, Quantitative, and Mixed Methods Approaches, 4th Edition. SAGE : California.

Depkop. (2020). Cooperatives in Pekanbaru City (Koperasi di Kota Pekanbaru). 2019. http://nik.depkop.go.id/, accessed 30 May 2020.

Effendi,. N. Herwany, A. and Masyita, D. (2018). Sustainability of Islamic Microfinance in Indonesia: A Holistic Approach. Academy of Strategic Management Journal, 17 (3). 
Al-Eid, N.A and Arnout, B.A. (2020). Crisis and Disaster Management in the Light of the Islamic Approach: COVID-19 Pandemic Crisis as a Model (A Qualitative Study Using the Grounded Theory). Journal of a Public Affairs. John Wiley \& Sons. https://doi.org/10.1002/pa.2217.

EKONID. (2020). COVID-19 Developments in Indonesia. https://indonesien.ahk.de/en/infocenter/news/news-details/covid19-developments-in-indonesia, accessed 11 August 2020.

Fitriani, A. (2020). The Effectiveness of Cash for Work in Handling the Impact of Covid-19. The $4^{\text {th }}$ International Conference of Zakat. Surabaya, 7-8 October, 2020.

Hardilawati, W.L. (2020). The Survival Stratgegy of SMEs during the COVID19. Jurnal Akuntansi \& Ekonomika, Vol.10 No.1, 89-98.

Hidayat, S.E., Farooq, M.A. and Halim, E.A. (2020). Impacts of the COVID-19 Outbreak on Islamic Finance in the OIC Countries. Jakarta:KNEKS, DinarStandard and Salaam Gateway.

Hidayat, S.E. (2020). Islamic Economy in ASEAN Countries During the Covid19 Era. International Webinar. Medan : Universitas Medan Area.

Hitt, M. A. R., Ireland, D. and Hoskisson, R.E. (2017). Strategic Management Competitiveness \& Globalization Concepts and Cases 12e. USA, Boston: Cengage Learning.

Huy, Q. (2020). Four Strategic Priorities for the Post-COVID-19 World. Strategy-Blog. https://knowledge.insead.edu/blog/insead-blog/fourstrategic-priorities-for-the-post-covid-19-world-14086, accessed in 12 August 2020.

Irfan, M. (2020). A Meta Analysis of Islamic Microfinance : Case Based Evidence from India. Journal of Islamic Monetary Economics and Finance, Vol.6, No.1, pp.21-50.

Khan, Q. (2020). How Islamic Microfinance Can Help during COVID-19 Sitution? An Alhuda (CIEMF) Plans Toward It. http://imfn.org/howislamic-microfinance-can-help-during-covid-19-situation-and-alhudaciemf-plans-toward-it, accessed 29 July 2020.

Khan, A. (2008). Islamic Microfinace : Theory, Policy and Practice. Birmingham, UK : Islamic Relief Worldwide.

Teck, G.L.H and Ho, C.M.C. (2020). Effects of the Coronavirus (COVID-19) Pandemic on Social Behaviours: From a Social Dilemma Perspective. Technium Social Sciences Journal, Vol 7, 312-320.

Malik, K., Meki, M., Morduck, J., Ogden, T., Quinn, S. and Said, F. (2020). COVID-19 and the Future of Microfinance: Evidence and Insights from Pakistan. Oxford Review of Economic Policy, Oxford University Press, 143.

Mediaindonesia. (2020). Ini 4 sektor Yang Paling Terpukul Covid-19. https://mediaindonesia.com/read/detail/300402-ini-4-sektor-yangpaling-terpukul-covid-19. Access date : Sept 24th 2020.

Merdeka. (2020). Dampak Corona, Ini 6 Sektor Yang Paling Terpengaruh Jika Terjadi Lock Down. https://www.merdeka.com/jatim/dampak- 
IMFIs Strategy to Survive in the Covid-19 Outbreak and Government Respond Analysis : An Empirical Study from Pekanbaru, Indonesia

corona-ini-6-sektor-yang-paling-terdampak-jika-terjadi-lockdownkln.html?page $=6$. Access date $:$ Sept $24^{\text {th }}, 2020$.

Smeru. (2020). Estimasi Dampak Pandemi Covid-19 Pada Kemiskinan Di Indonesia. https://smeru.or.id/id/content/estimasi-dampakpandemi-covid-19-pada-tingkat-kemiskinan-di-indonesia. Access date : Sept 24th, 2020.

Maikabara, A.A, Aderemi, A.M.R., and Maulida, S. (2020). Investigating the Viability of the Charity Based Model of Islamic Microfinance for Eradicting The Impact of Covid-19 on Social Wellbeing in Nigeria : A Descriptive Analysis. International Journal of Islamic Economics Perspectives, Vol.2, Issue 1.

Mawardi, I., Widiastuti, T., Al-Mustafa, M.U., and Prasetyo, A. (2020). Do Indonesian Islamic Microfinance Institutions Need Lender of the Last Resort?. Al-Uqud: Journal of Islamic Economics, 4 (2), p235-249.

Mindtools. (2007). Porter's Generic Strategies: Choosing Your Route to Success. https://www.mindtools.com/pages/article/newSTR_82.htm, accessed in 12 August 2020.

Tubastuvi, N. and Pratama, B.C.(2020). Competition And Net-Profit-And-Loss Sharing Margin In Indonesian Islamic Microfinance Institutions. Journal of Critical Reviews, 7 (8), 26992705. doi:10.31838/jcr.07.08.457

OECD. (2020). Coronavirus (COVID-19): SME Policy Responses.Tackling Coronavirus (COVID-19) Contributing to A Global Effort. 1-169.

Pekanbaru.

Sejarah

Pekanbaru. http://pekanbaru.go.id/p/hal/sejarah-pekanbaru, accessed 28 May 2020.

Rahayu, N.S. (2020). The Intersection of Islamic Microfinance and Women's Empowerment: A Case Study of Baitul Maal Wat Tamwil in Indonesia. International Journal of Financial Studies, 8 (37), 1-13.

Riwajanti, N.I. (2014). Islamic Microfinance in Indonesia : A Comparative Analysis between Islamic Financial Cooperative (BMT) and Shari'ah Rural Bank (BPRS) on Experience, Challenges, Prospects, and Roles in Developing Microenterprises. Bulletin of Indonesian Economic Studies, 50(3), 483-484.

Sekaran, U. and Roger, B. (2016). Research Methods for Business: A Skillbuilding Approach Seventh Edition. United Kingdom: John Wiley \& Sons Ltd.

Sultan, S. and Sultan, W.I.M. (2020). Women MSMEs in Time of Crisis : Challenges and Opportunities. Journal of Small business and Enterprise Development, Vol.27, No.7, pp.1069-1083.

Sumarni, Y. (2020). Islamic Economic Management in Handling Coronavirus Disease Pandemic (Manajemen Ekonomi Islam dalam Mengelola Pandemi Coronavirus Disease). Jurnal Baabu Al-Ilmi, Vol. 5, No. 1, 117 126. 
Suryahadi, A., Al Izzati, R. and Suryadarma, D. (2020). The Impact of COVID19 Outbreak on Poverty: An Estimation for Indonesia. Draft Working Paper: SMERU Research Insitute, Australian Government \& Knowledge Sector Initiative.

Syed, M.H., Khan, S., Rabbani, M.R., and Thalassinos, Y.E. (2020). An Artificial Intelligence and NLP Based Islamic FinTech Model Combining Zakat and Qardh-Al-Hasan for Countering the Adverce Impact of Covid-19 on SMEs and Individuals. International Journal of Economics and Business Administratio, Volume VIII, Issue 2.

Tribunnews. (2020). Teten Terbitkan Permenkop 4/2020, Syarat Usaha Calon Mitra Koperasi Jadi Lebih Simpel. https://www.tribunnews.com/nasional/2020/07/11/tetenterbitkan-permenkop-42020-syarat-usaha-calon-mitra-koperasi-jadilebih-simpel. Access date : Oct $2^{\text {nd }}, 2020$.

WHO. (2020). Coronavirus. https://www.who.int/healthtopics/coronavirus\#tab=tab_1, accessed 11 August 2020.

Worldometer. (2020). COVID-19 Coronavirus Pandemic. https://www.worldometers.info/coronavirus/?, accessed 11 August 2020.

Wheelen, T.L., Hunger, J.D., Hoffman, A.N. and Bamford, C.E. (2018). Strategic Management and Business Policy Globalization, Innovation and Sustainability.United Kingdom: Pearson Education.

Williams, C. (2007). Research Methods. Journal of Business and Economics Research, Grand Canyon University, Vo.5, No.3.

Zubair, M. K. (2016). Analysis of Sustainability Factors in Islamic Microfinance Institutions (Analisis Faktor-Faktor Sustainabilitas Lembaga Keuangan Mikro Syariah). Iqtishadia, Vol. 9 (2), p.201-226. 